\title{
TINJAUAN YURIDIS PELAYANAN KESEHATAN TERHADAP KORBAN ABORTUS PROVOCATUS KARENA PEMERKOSAAN
}

\section{Oleh}

\section{Anna Maria Salamor}

annamariasalamor@gmail.com

Ilmu Hukum, Fakultas Hukum, Universitas Pattimura

\begin{abstract}
ABSTRAK
Hubungan tanpa ikatan pernikahan kadang mengahasilkan bayi yang tidak diinginkan, bayi akan hadir kedunia ini akhirnya dilakukan upaya abortus provocatus tentunya mempunyai dampak kesehatan maupun dampak hukum. Pelayanan kesehatan terhadap kasus abortus provocatus karena pemerkosaan harus dilakukan oleh tenaga professional yang mendapatkan izin dan wewenang dari instansi terkait sesuai dengan Undang-Undang Nomor 36 tahun 2009 tentang Kesehatan maupun Peraturan Pemerintah Nomor 61 Tahun 2014 tentang Kesehatan Reproduksi yang berlaku. Selain itu aborsi yang dilakukan oleh korban pemerkosaan dapat dibenarkan sebab pada umumnya korban pemerkosaan rentan mengalami tekanan psikis yang akhirnya bisa membahayakan pada kondisi jiwanya. Sebagaimana yang diajarkan dalam ajaran mens rea dan actus reus dalam pertanggungjawaban pidana.
\end{abstract}

Kata Kunci: Abortus Provocatus, Pelayanan Kesehatan, Korban Pemerkosaan.

\begin{abstract}
A relationship without marriage bond sometimes results in an unwanted child, the baby will be born in this world eventually abortus provocatus attempts are made,
\end{abstract}


which surely has its health impact also legal impact. Health services towards abortus provocatus case because of rape should be done by the experts whose got the license and authority from a related institution based on current Law No. 36 of 2009 about Law on Health as well as Government Regulation No. 61 of 2014 about Reproduction Health. Furthermore, abortion done to the victim of rape is justifiable because generally, the victims are susceptible to experience psychological tension which at the end will harm her mental state. As taught in the teachings of mens rea and actus reus in criminal liability.

Keywords: Abortus Provocatus, Health Services, Rape Victim

\section{A. Pendahuluan}

Pada zaman modern saat ini, manusia mengalami perubahan karena ilmu pengetahuan yang terus menerus berkembang sehingga cara berfikir manusia semakin hari semakin maju. Namun sebaliknya, imbas dari perkembangan zaman itu sendiri tidak hanya bergerak kearah postif tetapi juga menawarkan sisi negatif karena sebenarnya perkembangan teknologi tersebut memiliki dampak bagi moral suatu bangsa. Dalam hal ini, salah satu sisi negatif yang timbul oleh perkembangan zaman tersebut adalah terjadinya tindak pidana aborsi yang dilakukan oleh perempuan baik yang sudah menikah maupun yang belum menikah.

Di Indonesia abortus provocatus lebih populer disebut aborsi. Maraknya aborsi dapat diketahui dari berita di surat kabar maupun media informasi lainnya seperti TV, internet, majalah. Namun sejauh ini kasus aborsi yang di proses sampai ketingkat pengadilan jumlahnya masih sedikit, berbanding terbalik dengan kasus-kasus pengguguran kandungan yang banyak ditemukan di masyarakat seperti dalam siaran pers catatan tahunan 
(CATAHU) komnas perempuan kasus pemerkosaan oleh orang yang memiliki hubungan darah yang dilaporkan terjadi selama tahun 2018 masih cukup tinggi mencapai 1071 kasus dalam satu tahun. ${ }^{1}$

Aborsi erat kaintanya dengan wanita dan janin yang ada dalam kandungan wanita tersebut. Aborsi selalu menjadi perbincangan baik dalam forum resmi maupun tidak resmi yang menyangkut bidang kedokteran, hukum maupun disiplin ilmu lainnya. ${ }^{2}$ Aborsi merupakan fenomena sosial yang semakin hari semakin memprihatinkan, karena sejauh ini perilaku pengguguran kandungan banyak menimbulkan efek negatif baik bagi diri pelaku maupun pada masyarakat luas. Berbicara tentang persoalan aborsi saat ini bukan lagi merupakan rahasia umum dan hal yang tabu untuk dibicarakan. Hal ini dikarenakan aborsi yang terjadi

http://www.komnasperempuan.go.id/readnews-siaran-tahuunan-komnas-perempuan2019

${ }^{2}$ Achadiat Charisdiono, Dinamika Etika dan Hukum Kedokteran, Jakarta: Buku Kedokteran, 2007, hal.12 dewasa ini sudah menjadi hal yang aktual dan peristiwanya terjadi dimana-mana serta dapat dilakukan oleh siapa saja baik itu secara legal maupun ilegal. Sejauh ini, persoalan aborsi dianggap oleh sebagian besar masyarakat sebagai tindak pidana. Namun dalam hukum positif di Indonesia tindakan aborsi pada sejumlah kasus tertentu dibenarkan apabila merupakan abortus provocatus medicinalis. Sedangkan aborsi yang digeneralisasi menjadi suatu tindak pidana lebih dikenal sebagai abortus provocatus criminalis. Dengan demikian terlepas dari persoalan apakah pelaku aborsi melakukannya atas dasar pertimbangan kesehatan (abortus provocatus medicinalis) atau melakukan tindakan tersebut dengan alasan lain yang kadang kala tidak dapat diterima dengan akal sehat, seperti kehamilan yang tidak dikehendaki (hamil luar nikah), takut tidak mampu membesarkan anak karena minimnya kondisi perekonomian keluarga atau karena merupakan korban pemerkosaan. 
Menurut peraturan perundangundangan di Indonesia aborsi adalah tindakan menggugurkan kandungan atau mematikan kandungan yang dilakukan dengan sengaja oleh seorang wanita atau orang yang disuruh melakukan aborsi.Dalam hal ini wanita hamil yang ingin menggugurkan kandungan, sedangkan orang yang menurut KUHP dapat disuruh untuk melakukan aborsi adalah tabib, bidan atau juru obat. ${ }^{3}$ Dengan demikan pengaturan mengenai aborsi diatur dalam pasal-pasal 299, 346,347,348 dan 349 KUHP. Dalam pasal-pasal tersebut dengan jelas dan tegas melarang dilakukannya aborsi dengan alasan apapun termasuk aborsi karena alasan darurat yaitu sebagai akibat pemerkosaan baik bagi pelaku maupun yang membantu melakukan aborsi. Namun dengan adanya UndangUndang Nomor 36 tahun 2009 tentang Kesehatan yang menggantikan Undang-Undang Nomor 23 Tahun 1992 serta Peraturan Pemerintah

${ }^{3}$ Moeljatno, Kitab Undang-Undang Hukum Pidana, Jakarta:Bumi Aksara, 2009, hal. 124
Nomor 61 Tahun 2014 tentang Kesehatan Reproduksi memberikan jaminan untuk dilakukannya aborsi dengan alasan adanya indikasi medis.

Berdasarkan uraian diatas, maka judul penulisan ini adalah Tinjauan Yuridis Pelayanan Kesehatan Terhadap Kasus Abortus Provocatus Karena Pemerkosaan. Oleh karena itu, permasalahan yang ingin dibahas adalah Bagaimakah Pelayanan Kesehatan Terhadap Kasus Abortus Provocatus Karena Pemerkosaan?

Penulisan ini bertujuan untuk mengetahui bagaimana aturan hukum mengenai korban pemerkosaan yang melakukan Abortus Provocatus dapatkah dibenarkan, sehingga tulisan ini mempunyai manfaat bagi penegakan hukum, korban pemerkosaan sering menjadi tersangka yang ditetapkan oleh penegak hukum, padahal hal ini salah. Mereka harus mengetahui sikap batin dari korban sehinngga melakukan Abortus Provocatus.

\section{B. Hasil dan Pembahasan}




\section{Pengertian Abortus Provocatus}

Dalam pengertian orang awam istilah aborsi adalah penguguran kandungan, keluarnya hasil konsepsi atau pembuahan sebelum waktunya. Menurut Black's Law Dictionary, abortion diterjemahkan sebagai "the spontaneous or artificially induced expulsion of an embryo or fetus. As used in illegal context refers to induced abortion". 4 Menurut Black's Law Dictionary, keguguran dengan keluarnya embrio atau fetus tidak semata-mata karena terjadi secara alamiah, akan tetapi juga disengaja atau terjadi karena adanya campur tangan manusia.

Di Indonesia abortus provocatus dikenal dengan istilah aborsi.Aborsi berasal dari bahasa Latin yang berarti pengguguran kandungan karena kesengajaan.Aborsi atau abortus provocatus adalah berakhirnya kehamilan dengan dikeluarkannya

\footnotetext{
${ }^{4}$ Subaidah Ratna Juita \& B.Rini Heryanti, Laporan PenelitianAbortus Provocatus Pada Korban Perkosaan Dalam Perspektif Hukum Pidana, diakses dari repository.usm.ac.id>files $>$ research tgl 7 mei 2019
}

janin (fetus) atau embrio sebelum memiliki kemampuan untuk bertahan hidup diluar rahim, sehingga mengakibatkan kematian. ${ }^{5}$

Menurut World Health Organization atau WHO abortus provocatus adalah ancaman atau pengeluaran hasil konsepsi sebelum janin dapat hidup diluar kandungan dan sebagai batasan digunakan kehamilan kurang dari 20 minggu atau berat janin kurang dari 500 gram atau sebelum 22 minggu. Diperkirakan keguguran spotan berkisar antar 1015\%.Namun demikian, frekuensi keseluruhan keguguran yang pasti sukar ditentukan karena ada banyak abortus buatan yang tidak dilaporkan kecuali bila terjadi komplikasi. ${ }^{6}$

Secara umum, Soerjono Soekanto mengemukakan beberapa istilah untuk menyebutkan keluarnya hasil konsepsi/pembuahan sebelum usia kehamilan 20 minggu yang biasa disebut aborsi/abortus diantaranya:

\footnotetext{
5 https://id.m.wikipedia.org/wiki/gugurkandunga diakses 7 mei 2019 http://regional.kompasiana.com, diakses 7 mei 2019
} 
1. Abortion criminals yaitu pengguguran kandungan yang bertentangan dengan hukum.

2. Abortion induced/abortion provoked/abortus provocatus yaitu pengguguran kandungan yang disengaja.

3. Abortion geugenic yaitu pengguguran kandungan untuk mendapatkan keturunan yang baik.

4. Abortion natural yaitu pengguguran kandungan secara alamiah.

5. Abortion spontaneous yaitu pengguguran kandungan secara tidak sengaja.

6. Abortion therapeutic yaitu pengguguran kandungan dengan tujuan untuk menjaga kesehatan sang ibu. ${ }^{7}$

Dalam pendekatan ilmu kesehatan dan kedokteran, aborsi terdiri dari dua macam yaitu aborsi spontan (abortus spontaneus) dan aborsi yang disengaja (abortus provocatus). Abortus provocatus ialah

7 Soejono Soekanto,Kamus Sosial, Jakarta:Raja Grafindo Persada,1993,hal.1 penghentian atau pengeluaran hasil kehamilan dari Rahim sebelum waktunya. ${ }^{8}$ Aborsi yang terjadi karena perbuatan manusia baik karena alasan medis misalnya karena wanita yang hamil menderita suatu penyakit dan untuk menyelamatkan nyawa wanita tersebut maka kandungan harus digugurkan atau dampak dari kehamilan yang tidak dikehendaki yang merupakan hasil pemerkosaan. Sedangkan aborsiyang disengaja dibedakan menjadi dua yaitu abortus provocatus criminalis dan abortus provocatus therapeuticus. ${ }^{9}$ Abortus provocatus Therapeuticus adalah pengguguran kandungan yang dilakukan dengan alat-alat tertentu dan dengan alasan bahwa kehamilan tersebut membahayakan atau dapat menyebabkan kematian si ibu.Sedangkan abortus provocatus criminalis adalah penguguran kandungan tanpa pembenaran alasan

8 SCJ,Kusumaryanto, Kontroversi Aborsi, Jakarta: PT Gramedia Indonesia, 2002, hal. 203

${ }^{9}$ Musa PerdanaKusuma, Bab-Bab tentang Kedokteran Forensik, Jakarta: Ghalia Indonesia, 1984, Hal.191 
medis dan dilarang oleh hukum.Abortus provocatus di Indonesia bersifat illegal, kecuali abortus provocatus therapeuticus.

\section{Pelayanan Kesehatan Terhadap Korban Abortus Provocatus Karena Pemerkosaan}

\footnotetext{
Berbicara tentang perempuan dan anak perempuan merupakan kelompok yang rentan sebagai korban pemerkosaan. Pemerkosaan dapat terjadi karena adanya faktor yang melatarbelakangi seperti dari cara pandang yang salah, faktor diri pribadi, faktor interaksi dengan lingkungan sekitar, dan faktor sosial masyarakat. Pemerkosaan merupakan bentuk konkrit terhadap perempuan. Pelaku pemerkosaan tidak menganggap perempuan sebagai manusia yang sederajat dengan dirinya, tetapi hanya menganggap perempuan sebagai objek seks semata yang dapat memuaskan nafsu birahinya.Oleh karena itu, korban tidak hanya menderita kerugian fisik, tetapi
}

juga psikis atau bahkan kerugian harta benda. Dengan demikian, pemerkosaan adalah suatu tindakan kriminal berwatak seksual yang terjadi ketika seorang manusia memaksakan manusia lain untuk melakukan hubungan seksual secara paksa baik dengan kekerasan atau ancaman kekerasan.

Tindak pidana pemerkosaan berkaitan erat dengan fungsi reproduksi perempuan dan dapat menimbulkan kehamilan yang tidak diinginkan. Jika korban pemerkosaan mengalami kehamilan, korban pada umumnya akan berusaha untuk menghentikan kehamilan tersebut karena akan membawa akibat buruk, seperti korban mengalami trauma yang panjang bahkan seumur hidup, korban juga tidak dapat melanjutkan pendidikan, tidak dapat bersosialisasi dengan lingkungan sekitarnya. Begitu juga jika anaknya lahir, masyarakat tidak siap menerima kehadirannya bahkan anak tersebut akan mendapat stigma sebagai anak haram yang tidak boleh bergaul dengan anak-anak lain 
di lingkungannya serta menerima perlakukan negatif. Adapun cara lain untuk menghentikan kehamilan yang tidak diingikan salah satunya dengan cara aborsi baik secara medis maupun non medis.

Secara umum KUHP telah menegaskan bahwa tindakan yang dilakukan oleh pihak-pihak yang terlibat dalam tindakan aborsi dapat dikenai sanksi pidana. Adanya pertanggungjawaban pidana bagi pelaku berdasarkan ketentuan Pasal 346, Pasal 347, Pasal 348 dan Pasal 349. Dalam KUHP tindakan aborsi secara jelas dan tegas dilarang tanpa pengecualian sehingga tidak ada perlindungan terhadap pelaku aborsi. Berbeda dengan KUHP yang tidak memberikan ruang sedikitpun terhadap tindakan aborsi. UndanganUndang Nomor 36 Tahun 2009 tentang Kesehatan pada dasarnya mealarang tindakan aborsi, namun larangan tersebut dapat dikecualikan dengan syarat-syarat tertentu yaitu dengan alasan adanya indikasi kedaruratan medis dan kehamilan akibat perkosaan yang diatur dalam ketentuan Pasal 75 ayat 2 butir (a) dan (b), serta dipertegas lagi dengan Peraturan Pemerintah Nomor 61 Tahun 2014 tentang Kesehatan Reproduksi khusus Pasal 31, Pasal 32, Pasal 33, Pasal 34, Pasal 35 Pasal 36, Pasal 37 dan Pasal 38. Muncul alasan dilakukan aborsi oleh Undang-Undang Nomor 36 Tahun 2009 diatur pada Bagian Keenam Kesehatan Reproduksi, mulai dari Pasal 75, Pasal 76 , dan pasal 77 sebagai berikut: ${ }^{10}$

a. Pasal 75, berbunyi:

1. Setiap orang dilarang melakukan aborsi

2. Larangan sebagaimana dimaksud pada ayat (1) dapat dikecualikan berdasarkan:

Indikasi kedaruratan medis dideteksi sejak usia dini kehamilan, baik yang mengancam nyawa ibu dan/atau janin, yang menderita penyakit genetik berat dan/atau cacat bawaan,

10 Dikutip dari Undang-Undang Nomor 36 Tahun 2009 tentang Kesehatan 


$$
\begin{aligned}
& \text { maupun yang tidak dapat } \\
& \text { diperbaiki sehingga } \\
& \text { menyulitkan bayi tersebut } \\
& \text { hidup diluar kandungan;atau } \\
& \text { a) Kehamilan } \\
& \text { akibat } \\
& \text { perkosaan yang } \\
& \text { dapat } \\
& \text { menyebabkan } \\
& \text { trauma } \\
& \text { psikologis bagi } \\
& \text { korban } \\
& \text { perkosaan. }
\end{aligned}
$$

3. Tindakan sebagaimana dimaksudkan pada ayat (2) hanya dapat dilakukan setelah melalui konseling dan/atau penasehatan pra tindakan dan diakhiri dengan konseling pasca tindakan yang dilakukan oleh konselor yang kompeten dan berwewenang.

4. Ketentuan lebih lanjut mengenai indikasi kedaruratan medis dan perkosaan, sebagaimana dimaksud pada ayat (2) dan ayat (3) diatur dengan peraturan pemerintah.

b. Pasal 76, berbunyi: Aborsi sebgaimana dimaksud dalam Pasal 75 hanya dapat dilakukan:

a) Sebelum kehamilan berumur 6 (enam) minggu dihitung dari hari pertama haid terakhir, kecuali dalam hal kedaruratan medis;

b) Oleh tenaga kesehatan yang memiliki keterampilan dan kewenangan yang memiliki sertifikat yang ditetapkan oleh menteri;

c) Dengan persetujuan ibu hamil yang bersangkutan;

d) Dengan izin suami kecuali korban perkosaan; dan 

e) Penyedia layanan kesehatan yang memenuhi syarat yang ditetapkan oleh meteri.

c. Pasal 77, berbunyi:

Pemerintah wajib melindungi dan mencegah perempuan dari aborsi sebagaimana diatur dalam Pasal 75 ayat (2) dan (3) yang tidak bermutu, tidak aman, dan tidak bertanggungjawab serta bertentangan dengan norma agama dan ketentuan perundang-undangan.

Pelaksanaan aborsi yang diatur dalam Undang-Undang Nomor 36 Tahun 2009 tentang kesehatan dipertegas dengan Peraturan Pemerintah Nomor 61 Tahun 2014 tentang Kesehatan Reproduksi Pasal 35 , berbunyi: ${ }^{11}$

1. Aborsi berdasrkan indikasi kedaruratan medis dan

${ }^{11}$ Dikutip dari Peraturan Pemerintah Nomor 61 Tahun 2014 tentang Kesehatan Reproduksi kehamilan akibat perkosaan harus dilakukan dengan aman, bermutu dan bertanggungjawab.

2. Praktek aborsi yang aman, bermutu dan bertanggungjawab sebagimana dimaksud ayat (1) meliputi:
a. Dilakukan oleh dokter sesuai standar,
b. Dilakukan difasilitasi pelayanan kesehatan yang memenuhi syarat yang ditetapkan oleh menteri,

c. Atas permintaan atau persetujuan perempuan hamil yang bersangkutan,

d. Dengan izin suami, kecuali korban perkosaan, e. Tidak diskriminatif, dan f. Tidak mengutamakan imbalan materi.

3. Dalam hal perempuan hamil sebagaimana dimaksud pada ayat 2 huruf (c) tidak dapat memberikan persetujuan, persetujuan aborsi dapat 
diberikan oleh keluarga yang bersangkutan.

4. Dalam hal suami tidak dapat dihubungi, izin sebagaimana ayat 2 huruf (d) di berikan oleh keluarga yang bersangkutan.

Selain itu dalam ketentuan Pasal 37 Peraturan Pemerinntah Nomor 61 Tahun 2014 tentang Kesehatan Reproduksi juga mengatur tentang aborsi yaitu:

1. Tindakan aborsi berdasarkan indikasi kedaruratan medis dan kehamilan akibat perkosaan hanya dapat dilakukan setelah konseling.

2. Konseling sebgaimana dimaksud pada ayat (1) meliputi konseling pra tindakan dan diakhiri dengan konseling pasca tindakan yang dilakukan oleh konselor.

3. Konseling pra tindakan sebagaimana ayat (2) dilakukan dengan tujuan: a. Menjajaki kebutuhan dari perempuan yang ingin melakukan aborsi;

b. Menyampaikan dan menjelaskan kepada perempuan yang ingin aborsi bahwa tindakan aborsi dapat atau tidak dapat dilakukan berdasarkan hasil pemeriksaan klinis dan pemeriksaan penunjang;

c. Menjelaskan tahapan tindakanaborsi yang akan dilakukan dan kemungkinan efek samping atau komplikasinya;

d. Membantu perempuan yang ingin melakukannya untuk mengambil keputusan sendiri untuk melakukan aborsi atau membatalkan keinginan untuk melakukan aborsi setelah mendapat informasi mengenai aborsi, dan 
e. Menilai kesiapan pasien untuk melakukan aborsi.

4. Konseling pasca tindakan sebagimana dimaksud pada ayat (2) dilakukan dengan tujuan:
a. Mengobservasi dan mengevaluasi kondisi pasien setelah tindakan aborsi;

b. Membantu pasien memahami keadaan atau kondisi fisik setalah menjalani aborsi;

c. Menjelaskan perlunya kunjungan ulang untuk pemeriksaan dan konseling lanjutan atau tindakan rujukan bila diperlukan; dan

d. Menjelaskan pentingnya $\begin{array}{lr}\text { penggunaan } & \text { alat } \\ \text { kontrasepsi } & \text { untuk } \\ \text { mencegah } & \text { terjadinya } \\ \text { kehamilan. } & \end{array}$

Selain itu aborsi hanya boleh dilakukan dengan oleh dokter dengan tujuan pengobatan yang wajib dilaksanakan berdasarkan sumpah jabatan. Dalam kode etik kedokteran Indonesia (KODEKI) pada Pasal 10 KODEKI dikatakan bahwa setiap dokter harus senantiasa mengingat kewajiban makhluk insani.

Berdasarkan rangkaian bunyi pasal-pasal baik dalam UndangUndang Nomor 36 Tahun 2009 tentang Kesehatan maupun Peraturan Pemerintah Nomor 61 Tahun 2014 tentang Kesehatan Reproduksi belum terimplementasikan secara maksimal dan sempurna soal aborsi. Dikarenakan adanya perbedaan waktu antara UU dan PP dengan SOP yang dimiliki oleh PKBI. Dalam Pasal 37 Undang-Undang Nomor 36 tahun 2009 tentang Kesehatan hanya memberikan waktu sekitar 6 minggu terhitung sejak haid pertama haid terakhir sedangkan dalam Peraturan Pemerintah Nomor 61 Tahun 2014 tentang Kesehatan Reproduksi pada Pasal31 ayat 2 hanya 40 hari dihitung haid pertama haid terakhir, bila dibandingan dengan SOP PKBI indikasi dapat dilakukan aborsi sekitar 10 minggu. Oleh karena itu 
langkah-langkah pelayaan kesehatan terhadap kasus abortus provocatus karena pemerkosaan sebagai berikut:

a. Pengguguran

kandungan hanya

dilakukan sebagai

tindakan terapeutik

b. Tindakan penguguran kandungan dilakukan apabila usia kandungan dibahwa 12 minggu. Karena pada usia tersebut kemungkinan rasa sakit atau kematian sangat kecil.

c. Suatu keputusan untuk menghentikan

kehamilan sedapat mungkin disetujui secara tertulis oleh dua orang dokter yang dipilih sesuai dengan bidang keahlian mereka.

d. Prosedurnya hendak dilakukan oleh seorang dokter yang kompeten dan berwewenang serta telah diakui oleh instansi tersebut.

e. Jika dokter merasa bahwa hati nuraninya tidak membenarkan tindakan tersebut maka ia boleh mengundurkan diri.

f. Didukung oleh peralatan medis yang lengkap dan memadai.

g. Sebelum dan sesudah aborsi harus dilakukan konseling terhadap pasien.

Dengan demikian yang menjadi alasan utama mengapa para korban pemerkosaan diperbolehkan untuk mengugurkan kandungan meraka, karena kondisi psikis korban yang tertekan akibat tragedi yang dialami, kehamilan yang tidak diingikan menjadi beban dan aib bagi mereka.

\section{Penutup}

Berdasarkan uraian dalam pembahasan, dapat disimpulan bahwa pelayanan kesehatan terhadap kasus 
abortus provocatus karena Reproduksi yang berlaku. Selain itu pemerkosaan harus dilakukan oleh aborsi yang dilakukan oleh korban tenaga professional yang mendapatkan pemerkosaan dapat dibenarkan sebab izin dan wewenang dari instansi terkait pada umumnya korban pemerkosaan sesuai dengan Undang-Undang Nomo rentan mengalami tekanan psikis yang 36 tahun 2009 tentang Kesehatan akhirnya bisa membahayakan pada maupun Peraturan Pemerintah Nomor kondisi jiwanya.

61 Tahun 2014 tentang Kesehatan

\section{Daftar Pustaka}

B. Rini Heryanti, S. R. (2010). Abortus Provocatus Pada Korban Pemerkosaan dalam Perspektif Hukum Pidana.

Charisdiono, A. (2007). Dinamika Etika dan Hukum Kedokteran. Jakarta: Buku Kedokteran.

Kusumaryanto, S. (2002). Konversi Aborsi. Jakarta: PT Gramedia Indonesia.

Moeljatno. (2009). Kitab Undang-Undang Hukum Pidana. Jakarta: Bumi Aksara.

Salamor, A. M. (2015). ABORTUS PROVOCATUS KARENA KEGAGALAN ALAT KONTRASEPSI DALAM PERSPEKTIF PEMBAHARUAN HUKUM NASIONAL. Law Reform .

Undang-Undang Nomor 36 Tahun 2009 tentang Kesehatan

Peraturan Pemerintah Nomor 61 Tahun 2014 tentang Kesehatan Reproduksi

https://www.komnasperempuan.go.id/

https://id.m.wikipedia.org/

https://regional kompasiana.com 